\title{
IZUMO1 is a sperm fusogen
}

Nicolas G. Brukman ${ }^{1 *}$, Kohdai P. Nakajima ${ }^{2}$, Clari Valansi ${ }^{1}$, Xiaohui Li ${ }^{1}$, Tetsuya Higashiyama ${ }^{2,3,4 \#}$, Benjamin Podbilewicz ${ }^{1 \#}$

${ }^{1}$ Department of Biology, Technion- Israel Institute of Technology, Haifa 32000, Israel

${ }^{2}$ Division of Biological Science, Graduate School of Science, Nagoya University,

Furo-cho, Chikusa-ku, Nagoya, Aichi 464-8602, Japan

${ }^{3}$ Institute of Transformative Bio-Molecules (WPI-ITbM), Nagoya University, Furo-cho, Chikusa-ku, Nagoya, Aichi 464-8601, Japan

${ }^{4}$ Department of Biological Sciences, Graduate School of Science, the University of

Tokyo, 7-3-1 Hongo, Bunkyo-ku, Tokyo 113-0033, Japan

*These authors contributed equally.

\#Correspondence and requests for materials should be addressed to N.G.B, T.H. or B.P.

\section{Abstract}

Mammalian sperm-egg adhesion depends on the trans-interaction between the sperm-specific type I glycoprotein IZUMO1 and its oocyte-specific GPI-anchored receptor JUNO. However, the mechanisms and proteins (fusogens) which mediate the following step of gamete fusion remain unknown. Here we unveil an unexpected function for IZUMO1 in cell-to-cell fusion. Using content mixing and live-imaging assays in heterologous cells we found that IZUMO1 is a unilateral fusogen that acts independently of JUNO. IZUMO1-mediated fusion is abrogated by deletion of a $\beta$ hairpin that was previously reported to be required for JUNO-IZUMO1 transinteractions. Our findings suggest a dual function for IZUMO1 in mouse gamete fusion.

\section{Introduction}

The molecular mechanisms of the ultimate steps of mammalian egg-sperm fusion remain a mystery. Cell fusion requires the action of specialized proteins, named fusogens, to overcome the energetic barriers that arise when the plasma membranes come into close proximity (1). By definition, fusogens are both essential in their system of origin (in situ) and sufficient to induce membrane merging in otherwise non-fusing heterologous systems. Some proteins expressed in the oocyte or in the sperm were shown to be essential for fertilization (2), including the cross-interacting proteins IZUMO1 and JUNO/IZUMO1R. IZUMO1 was the first sperm protein whose deletion led to a block in mouse gamete fusion (3), while JUNO was identified as the IZUMO1 receptor in the oocyte (4). The IZUMO1-JUNO trans-interaction is required for efficient 
sperm-egg binding (5) but was found to be insufficient to fuse the plasma membranes of Human Embryonic Kidney HEK293T cells (4). Here, however, we present evidence that the expression of mouse IZUMO1 is sufficient to mediate cell-cell fusion, thus underpinning an additional role for this protein in membrane merging during fertilization.

\section{Results and Discussion}

Non-fusogenic Baby Hamster Kidney (BHK) cells have been used to test for fusogenic activity of candidate proteins $(6,7)$. To find the missing gamete fusogen(s) in mammals, we aimed to evaluate candidate gamete-specific proteins using this system, with mouse JUNO and IZUMO1 as negative controls to account for proteins involved in binding, but not fusion. To our surprise, when we expressed IZUMO1, but not JUNO, we observed syncytia formation at levels similar to those in the positive control GCS1/HAP2 (GENERATIVE CELL-SPECIFIC 1/HAPLESS 2), a gamete fusogen from Arabidopsis thaliana (Fig. 1A). We found that multinucleation increased significantly when IZUMO1 was expressed compared to the negative control containing a membrane-bound myristoylated EGFP (myrGFP) (Fig. 1B). For both IZUMO1 and GCS1/HAP2, we found an increase in cells with two-, three-, four- and even five-nuclei (Table S1).

Following the observation that IZUMO1 can induce multinucleation we aimed to test the ability of IZUMO1 and JUNO to mediate cell-cell fusion by using content mixing experiments $(6,7)$. In this assay, two populations of BHK cells expressing either cytosolic EGFP (GFPnes) or nuclear H2B-RFP are co-incubated and the appearance of multinucleated cells containing both fluorescent markers is monitored as an indication of fusion (Fig. 2A and Fig. S1). Under these conditions, IZUMO1 induced a 5.5-fold increase in the content mixing of BHK cells compared to the controls employing the fluorescent empty vectors (Fig. 2B); a 4-fold increase was observed in the positive GCS1/HAP2 control. As in the syncytia formation assay, expression of JUNO failed to induce content mixing. Interestingly, content mixing was also observed when IZUMO1 was present only in one of the two populations of cells that were mixed, implying a unilateral fusion mechanism (Fig. 2). The presence of JUNO in trans of IZUMO1 appears to increase the number of fusion events, which may be due to increased association between cells from the two populations as a result of IZUMO1JUNO interaction. To determine whether IZUMO1 can merge different heterologous cells, we performed content mixing assays using human HEK293T cells and obtained similar results (Figs. S2 and S3).

To independently study the fusogenic activity of IZUMO1, we performed live imaging experiments to track fusion events of BHK cells in real time (Fig. S4). For this purpose, we transfected cells with a plasmid encoding for cytoplasmic RFP (RFPcyto) alone, for the negative control, or together with a mifepristone-inducible system to express our candidate proteins. As a positive control we used EFF-1, a somatic fusogen from Caenorhabditis elegans (6). Vectors for E-cadherin, GEX2 (Gamete 
EXpressed 2), IZUMO1 and JUNO were similarly prepared and the cells were visualized upon induction. As expected, cell-cell fusion was observed following EFF-1 expression (Fig. 3A; Video 1). Cell-cell fusion events were quantified $12 \mathrm{~h}$ after induction. We found that EFF-1 expression significantly increased fusion levels (Fig. 3B), whereas the adhesion proteins (E-cadherin, GEX2 and JUNO) did not display fusogenic activity; significantly, IZUMO1 induced fusion albeit to somewhat lower levels than EFF-1 (Fig. 3A; Video 2). Because IZUMO1 was expressed as a Venus fusion we could follow its expression; we often observed Venus fluorescence at time points when fusion started taking place (Fig. 3A; Video 2). A $\beta$-hairpin region of IZUMO1 is required for JUNO binding $(8,9)$. To determine whether this region plays a role in fusion as well, we expressed a mutant containing a deletion of the $\beta$-hairpin $($ IZUMO1 $\triangle$ ). We found that cell-cell fusion was impaired in this mutant (Fig. 3B) which was not due to a decreased expression compared to its wild type counterpart (Fig. 3C).

IZUMO1 contains the so-called Izumo domain composed of a four-helix bundle in the N-terminal part, linked to an Ig-like domain by a $\beta$-hairpin or hinge (Fig. $4 ;(10)$ ). There is no obvious homology between IZUMO1 and any known fusogen, but it shares structural similarities with proteins involved in cell invasion of malaria parasites (10). Additionally, IZUMO1 lacks any obvious hydrophobic stretch that could work as a fusion peptide or loop which serves to anchor to the opposing membrane (8), a characteristic feature which is shared by multiple cellular and viral fusogens (11). However, solvent-exposed bulky hydrophobic residues are present in the Izumo domain (10); these residues which are not involved in JUNO-IZUMO1 interaction (8, 9 ) might be relevant for interacting with the egg membrane. Interestingly, monoclonal antibodies against the N-terminal region of IZUMO1 were capable of inhibiting gamete fusion in vitro without altering sperm binding to the oocyte (12), supporting not only an additional role of IZUMO1 in fusion besides binding, but also a relevance of the Izumo domain in these later stages of fertilization. It is also established that after sperm binding JUNO is excluded from the interface between egg and sperm, while IZUMO1 is conversely enriched in this region (13). These observations are all consistent with a role of IZUMO1 as a fusogen. The concentration of IZUMO1 at the fusion zone is accompanied by a conformational change that depends on disulfide isomerase activity, and dimerization (13). Our results suggest a role for the IZUMO1 $\beta$-hairpin hinge in cell-cell fusion (Fig. 3B), which might be due to its potential role in mediating a conformational change. The more ancestral origin of IZUMO1 compared to JUNO, which is only present in mammals (14), as well as IZUMO1's unilateral fusogenic activity, further suggest a function for IZUMO1 in fertilization that is independent of its well-established interaction with JUNO.

Although our results point to IZUMO1 as a bona fide fusogen that can fuse hamster and human cells in culture, this does not exclude the possibility that other fusogenic proteins work cooperatively with IZUMO1 to ensure the success of fertilization in vivo $(12,13,15-18)$. Closely related proteins to IZUMO1, for instance, IZUMO2-4, 
SPACA6 or TMEM95 may work as fusogens or potentiate IZUMO1's activity $(16,17)$. Notably, IZUMO1 can homo- and hetero-oligomerize $(16,18)$. From the egg side, CD9 shows signals of co-evolution with IZUMO1 suggesting functional or physical interactions $(19,20)$. The fact that eukaryotic fusogens (e.g. EFF-1, AFF-1 and GCS1) were shown to be less efficient than their viral counterparts $(6,7)$ might also contribute to explain why previous studies failed to detect fusion of cells expressing IZUMO1 and JUNO (4)

Up to this report, GCS1/HAP2 proteins were the only known fusogens involved in fertilization $(21,22)$; these proteins are structurally and evolutionarily related to Class II fusogens from enveloped viruses and FF fusogens from nematodes $(7,23,24)$. Together, these fusogens form a superfamily called Fusexins. The involvement of GCS1/HAP2 in gamete fusion seems to be a characteristic of eukaryotes $(7,24)$; however, many sexually reproducing organisms including fungi and vertebrates lack a fusexin homologue. Considering their distributions in the phylogenetic tree (25), it is possible that IZUMO1-type proteins replaced GCS1/HAP2 during evolution as a strategy for gamete fusion. Combined with previous information $(12,13,16,17)$, and in analogy with the intracellular fusogens such as the SNAREs complex that require the regulatory activities of Munc18, Munc13 and synaptotagmin for efficient fusion (26), we hypothesize that IZUMO1 first transiently binds JUNO for docking and subsequently undergoes a conformational change and oligomerization that induce fusion (Fig. 4). This role in membrane merging makes IZUMO1 even more suited to its name, coined after the Japanese shrine dedicated to marriage (3).

\section{Acknowledgments}

We thank Gavin Wright for the plasmids containing mlzumo1 and mJuno sequences. We thank Pablo Aguilar, Dan Cassel, Masahito Ikawa, Yael losilevskii and Luca Jovine for critically reading the manuscript. Funding: This work was funded by the Israel Science Foundation (ISF grants 257/17, 2462/18, 2327/19 and 178/20 to B.P.), by Grant-in-Aid for Scientific Research on Innovative Areas (16H06465, 16H06464, and 16K21727 to T.H.), by JST, ERATO (JPMJER1004 to T.H.) and CREST (JPMJCR20E5 to T.H.). This project has received funding from the European Union's Horizon 2020 research and innovation programme under the Marie Skłodowska-Curie grant agreement No 844807. Author contributions: B.P. and T.H. conceived the study. N.G.B., K.P.N., C.V. and X.L. designed and conducted experiments, and processed and analyzed the data supervised by B.P. and T.H.; N.B. and B.P. wrote the initial draft of the manuscript. All authors participated in discussions of results and manuscript editing. Competing interests: The authors declare no competing interests. Data and materials availability: all data is available in the manuscript or the supplementary materials. 


\section{$\underline{\text { References }}$}

1. L. V. Chernomordik, M. M. Kozlov, Protein-Lipid Interplay in Fusion and Fission of Biological Membranes*.

http://dx.doi.org/10.1146/annurev.biochem.72.121801.161504. 72, 175-207 (2003).

2. E. Bianchi, G. J. Wright, Find and fuse: Unsolved mysteries in sperm-egg recognition. PLoS Biol. 18, e3000953 (2020).

3. N. Inoue, M. Ikawa, A. Isotani, M. Okabe, The immunoglobulin superfamily protein Izumo is required for sperm to fuse with eggs. Nature. 434, 234-238 (2005).

4. E. Bianchi, B. Doe, D. Goulding, G. J. Wright, Juno is the egg Izumo receptor and is essential for mammalian fertilization. Nature. 508, 483-487 (2014).

5. T. Matsumura, T. Noda, Y. Satouh, A. Morohoshi, S. Yuri, M. Ogawa, Y. Lu, A. Isotani, M. Ikawa, Sperm IZUMO1 is required for binding preceding fusion with oolemma in mice and rats. Frontiers in Cell and Developmental Biology. 9, 3849 (2021).

6. O. Avinoam, K. Fridman, C. Valansi, I. Abutbul, T. Zeev-Ben-Mordehai, U. E. Maurer, A. Sapir, D. Danino, K. Grünewald, J. M. White, B. Podbilewicz, Conserved eukaryotic fusogens can fuse viral envelopes to cells. Science. 332, 589-592 (2011).

7. C. Valansi, D. Moi, E. Leikina, E. Matveev, M. Graña, L. V. Chernomordik, H. Romero, P. S. Aguilar, B. Podbilewicz, Arabidopsis HAP2/GCS1 is a gamete fusion protein homologous to somatic and viral fusogens. J. Cell Biol. 216, 571581 (2017).

8. H. Aydin, A. Sultana, S. Li, A. Thavalingam, J. E. Lee, Molecular architecture of the human sperm IZUMO1 and egg JUNO fertilization complex. Nature. 534, 562-565 (2016).

9. U. Ohto, H. Ishida, E. Krayukhina, S. Uchiyama, N. Inoue, T. Shimizu, Structure of IZUMO1-JUNO reveals sperm-oocyte recognition during mammalian fertilization. Nature. 534, 566-569 (2016).

10. K. Nishimura, L. Han, E. Bianchi, G. J. Wright, D. de Sanctis, L. Jovine, The structure of sperm Izumo1 reveals unexpected similarities with Plasmodium invasion proteins. Curr. Biol. 26, R661-2 (2016).

11. N. G. Brukman, B. Uygur, B. Podbilewicz, L. V. Chernomordik, How cells fuse. J. Cell Biol. 218, 1436-1451 (2019).

12. N. Inoue, D. Hamada, H. Kamikubo, K. Hirata, M. Kataoka, M. Yamamoto, M. Ikawa, M. Okabe, Y. Hagihara, Molecular dissection of IZUMO1, a sperm protein essential for sperm-egg fusion. Development. 140, 3221-3229 (2013).

13. N. Inoue, Y. Hagihara, D. Wright, T. Suzuki, I. Wada, Oocyte-triggered 
dimerization of sperm IZUMO1 promotes sperm-egg fusion in mice. Nat. Commun. 6, 8858 (2015).

14. P. Grayson, Izumo1 and Juno: the evolutionary origins and coevolution of essential sperm-egg binding partners. Royal Society Open Science. 2 (2015), doi:10.1098/RSOS.150296.

15. M. Chalbi, V. Barraud-Lange, B. Ravaux, K. Howan, N. Rodriguez, P. Soule, A. Ndzoudi, C. Boucheix, E. Rubinstein, J. P. Wolf, A. Ziyyat, E. Perez, F. Pincet, C. Gourier, Binding of sperm protein Izumo1 and its egg receptor Juno drives Cd9 accumulation in the intercellular contact area prior to fusion during mammalian fertilization. Development. 141, 3732-3739 (2014).

16. D. A. Ellerman, J. Pei, S. Gupta, W. J. Snell, D. Myles, P. Primakoff, Izumo is part of a multiprotein family whose members form large complexes on mammalian sperm. Mol. Reprod. Dev. 76, 1188-1199 (2009).

17. V. E. Deneke, A. Pauli, The Fertilization Enigma: How Sperm and Egg Fuse. Annu. Rev. Cell Dev. Biol. 37, 391-414 (2021).

18. A. S. Gaikwad, A. L. Anderson, D. J. Merriner, A. E. O'Connor, B. J. Houston, R. J. Aitken, M. K. O'Bryan, B. Nixon, GLIPR1L1 is an IZUMO-binding protein required for optimal fertilization in the mouse. BMC Biol. 17, 86 (2019).

19. A. Vicens, E. R. S. Roldan, Coevolution of positively selected IZUMO1 and CD9 in rodents: evidence of interaction between gamete fusion proteins? Biol. Reprod. 90, 113 (2014).

20. K. G. Claw, R. D. George, W. J. Swanson, Detecting coevolution in mammalian sperm-egg fusion proteins. Mol. Reprod. Dev. 81, 531-538 (2014).

21. K. von Besser, A. C. Frank, M. A. Johnson, D. Preuss, Arabidopsis HAP2 (GCS1) is a sperm-specific gene required for pollen tube guidance and fertilization. Development. 133, 4761-4769 (2006).

22. T. Mori, H. Kuroiwa, T. Higashiyama, T. Kuroiwa, GENERATIVE CELL SPECIFIC 1 is essential for angiosperm fertilization. Nat. Cell Biol. 8, 64-71 (2006).

23. J. Fédry, Y. Liu, G. Péhau-Arnaudet, J. Pei, W. Li, M. A. Tortorici, F. Traincard, A. Meola, G. Bricogne, N. V. Grishin, W. J. Snell, F. A. Rey, T. Krey, The Ancient Gamete Fusogen HAP2 Is a Eukaryotic Class II Fusion Protein. Cell. 168, 904-915.e10 (2017).

24. J. F. Pinello, A. L. Lai, J. K. Millet, D. Cassidy-Hanley, J. H. Freed, T. G. Clark, Structure-function studies link class II viral fusogens with the ancestral gamete fusion protein HAP2. Curr. Biol. 27, 651 (2017).

25. T. D. R. Vance, J. E. Lee, Virus and eukaryote fusogen superfamilies. Curr. Biol. 30, R750-R754 (2020).

26. K. P. Stepien, J. Rizo, Synaptotagmin-1-, Munc18-1-, and Munc13-1- 
dependent liposome fusion with a few neuronal SNAREs. Proc. Natl. Acad. Sci. U. S. A. 118 (2021), doi:10.1073/pnas.2019314118.

27. K. P. Nakajima, C. Valansi, D. Kurihara, N. Sasaki, B. Podbilewicz, T. Higashiyama, A Novel Live Imaging-Based Assay for Visualising SpeciesSpecific Interactions in Gametic Adhesion Molecules. Research Square (2021), doi:10.21203/rs.3.rs-1174354/v1.

28. R. M. Williams, U. Senanayake, M. Artibani, G. Taylor, D. Wells, A. A. Ahmed, T. Sauka-Spengler, Genome and epigenome engineering CRISPR toolkit for in vivo modulation of cis-regulatory interactions and gene expression in the chicken embryo. Development. 145 (2018), doi:10.1242/dev.160333.

29. D. Moi, S. Nishio, X. Li, C. Valansi, M. Langleib, N. G. Brukman, K. Flyak, C. Dessimoz, D. de Sanctis, K. Tunyasuvunakool, J. Jumper, M. Graña, H. Romero, P. S. Aguilar, L. Jovine, B. Podbilewicz, Archaeal origins of gamete fusion. bioRxiv, 2021.10.13.464100 (2021).

30. V. Dunsing, M. Luckner, B. Zühlke, R. A. Petazzi, A. Herrmann, S. Chiantia, Optimal fluorescent protein tags for quantifying protein oligomerization in living cells. Sci. Rep. 8, 10634 (2018).

31. L. F. Liang, S. M. Chamow, J. Dean, Oocyte-specific expression of mouse Zp-2: developmental regulation of the zona pellucida genes. Mol. Cell. Biol. 10, 15071515 (1990).

32. M. Truffi, V. Dubreuil, X. Liang, N. Vacaresse, F. Nigon, S. P. Han, A. S. Yap, G. A. Gomez, J. Sap, RPTPa controls epithelial adherens junctions, linking Ecadherin engagement to c-Src-mediated phosphorylation of cortactin. J. Cell Sci. 127, 2420-2432 (2014). 
A
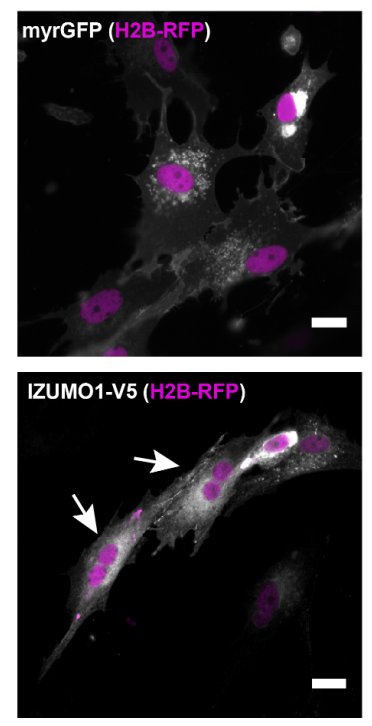

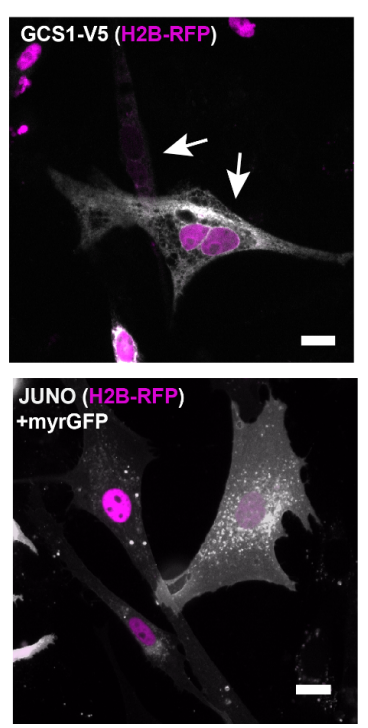

B

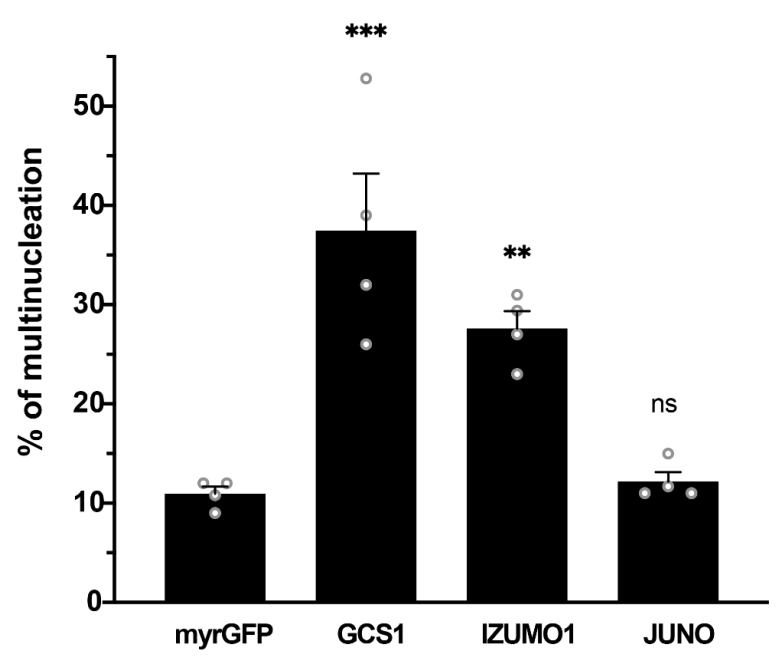

Figure 1 | IZUMO1 induces multinucleation of BHK cells. (A) Cells were transfected with pCl::myrGFP::H2B-RFP (myristoylated EGFP), pCl::GCS1/HAPV5::H2B-RFP, pCl::IZUMO1-V5:H2B-RFP or pCl::JUNO::H2B-RFP vectors. For JUNO a plasmid for myrGFP (gray) was co-transfected. Immunofluorescence was performed with anti-V5 antibodies for IZUMO1 and GCS1/HAP2 (gray). Arrows show cells with more than one nucleus (magenta). Scale Bars, $20 \mu \mathrm{m}$. (B) The percentage of multinucleation (see Supplementary Information) is presented as individual data and means \pm SEM of four independent experiments. The number of cells counted can be found in Table S1. Comparisons were made with one-way ANOVA followed by Dunnett's test against the empty vector. ns $=$ non-significant, ${ }^{* *} p<0.01,{ }^{* * *} p<0.001$. 
A
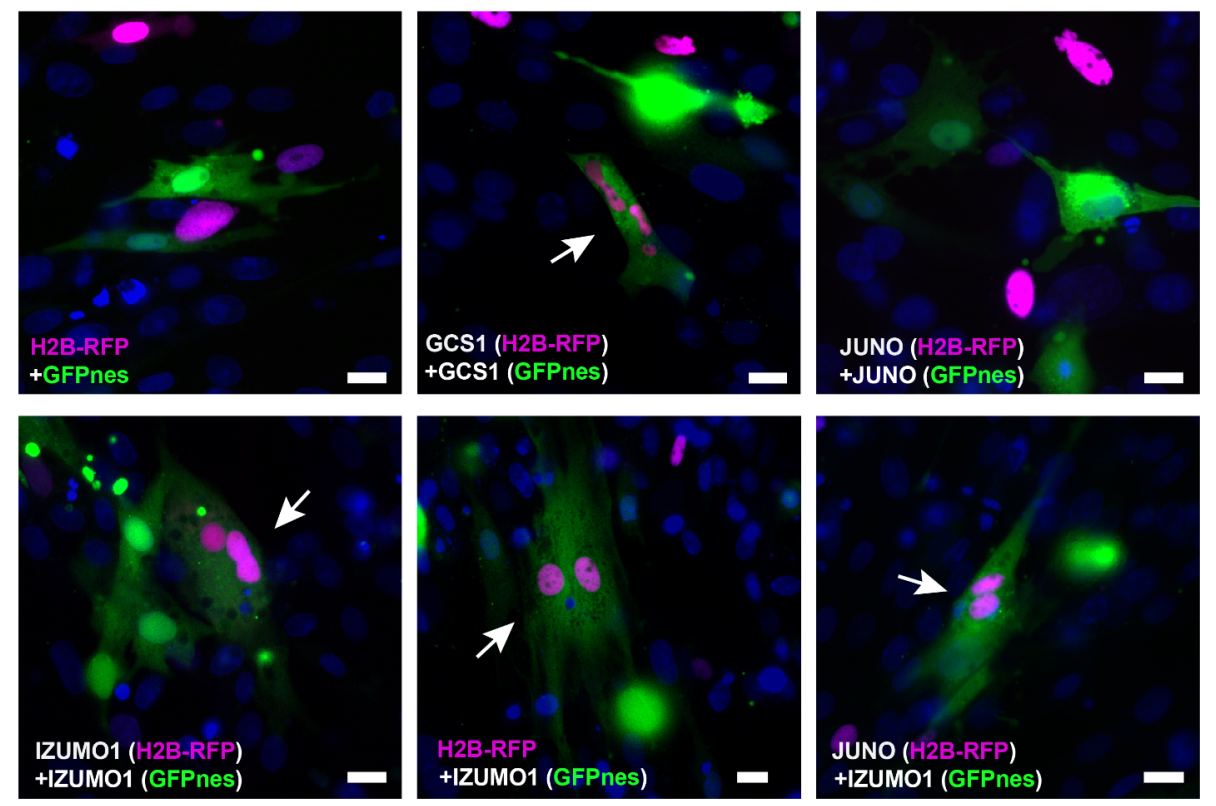

B

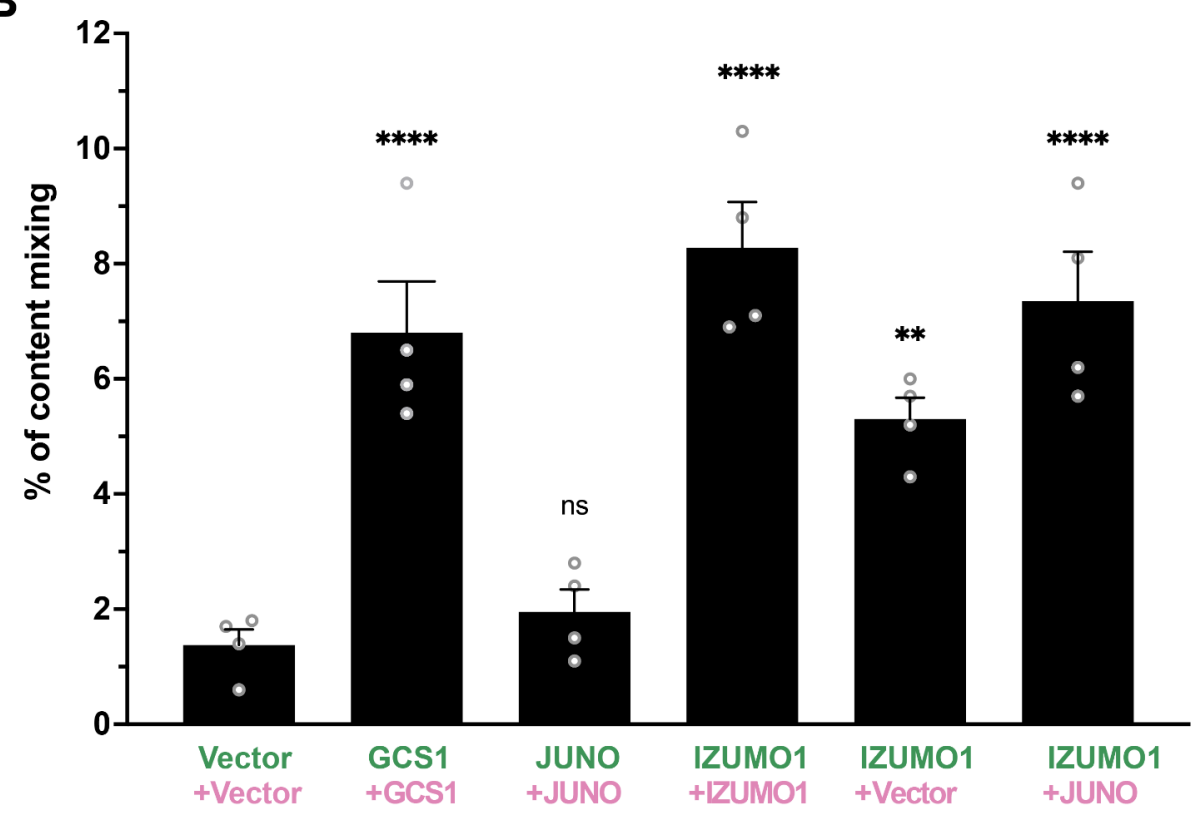

Figure 2 | Evaluation of cell fusion by content mixing of BHK cells. (A) Images of mixed cells transfected with pCl::GFPnes or pCl::H2B-RFP empty or containing the coding sequence for the expression of GCS1/HAP2, IZUMO1 and JUNO as indicated in each panel. Arrows show fused cells containing both fluorescent markers, green cytoplasm (GFPnes) with red nuclei (H2B-RFP). DAPI staining is shown in blue. Scale Bars, $20 \mu \mathrm{m}$. (B) Quantification of content-mixing experiments. The percentage of mixing was defined as the ratio between the nuclei in mixed cells (NuM) and the total number of nuclei in mixed cells and fluorescent cells in contact that did not fuse (NuC), as follows: $\%$ of mixing $=(\mathrm{NuM} /(\mathrm{NuM}+\mathrm{NuC})) \times 100$. Bar chart showing individual experiment values and means \pm SEM of four independent experiments. Comparisons by one-way ANOVA followed by Dunnett's test against the empty vectors. ns = nonsignificant, ${ }^{* *} p<0.01,{ }^{* * * *} p<0.0001$. 
A
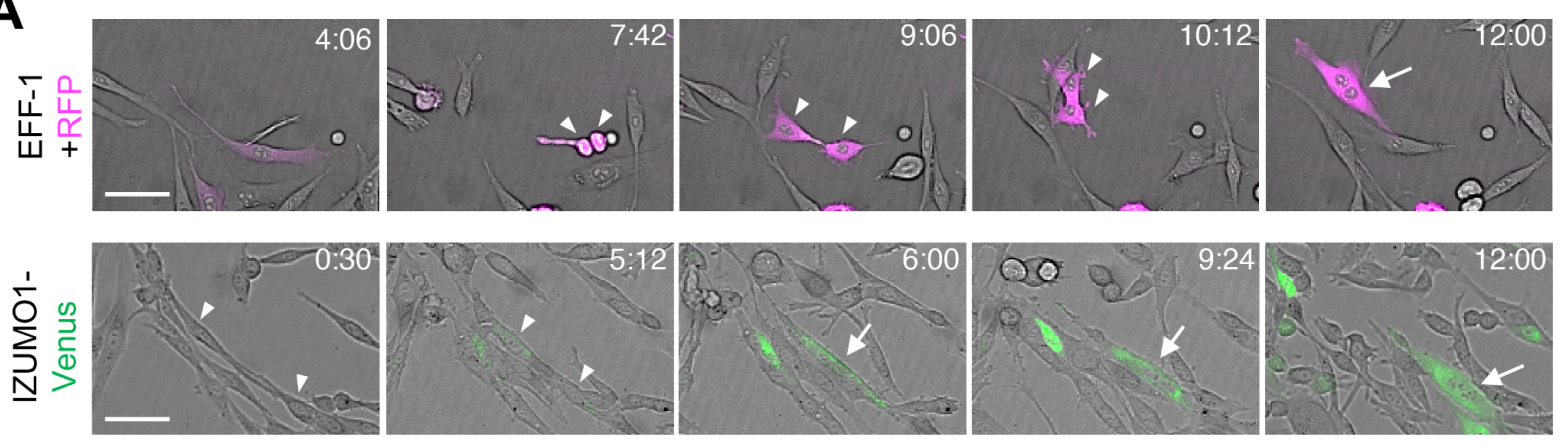

B

C
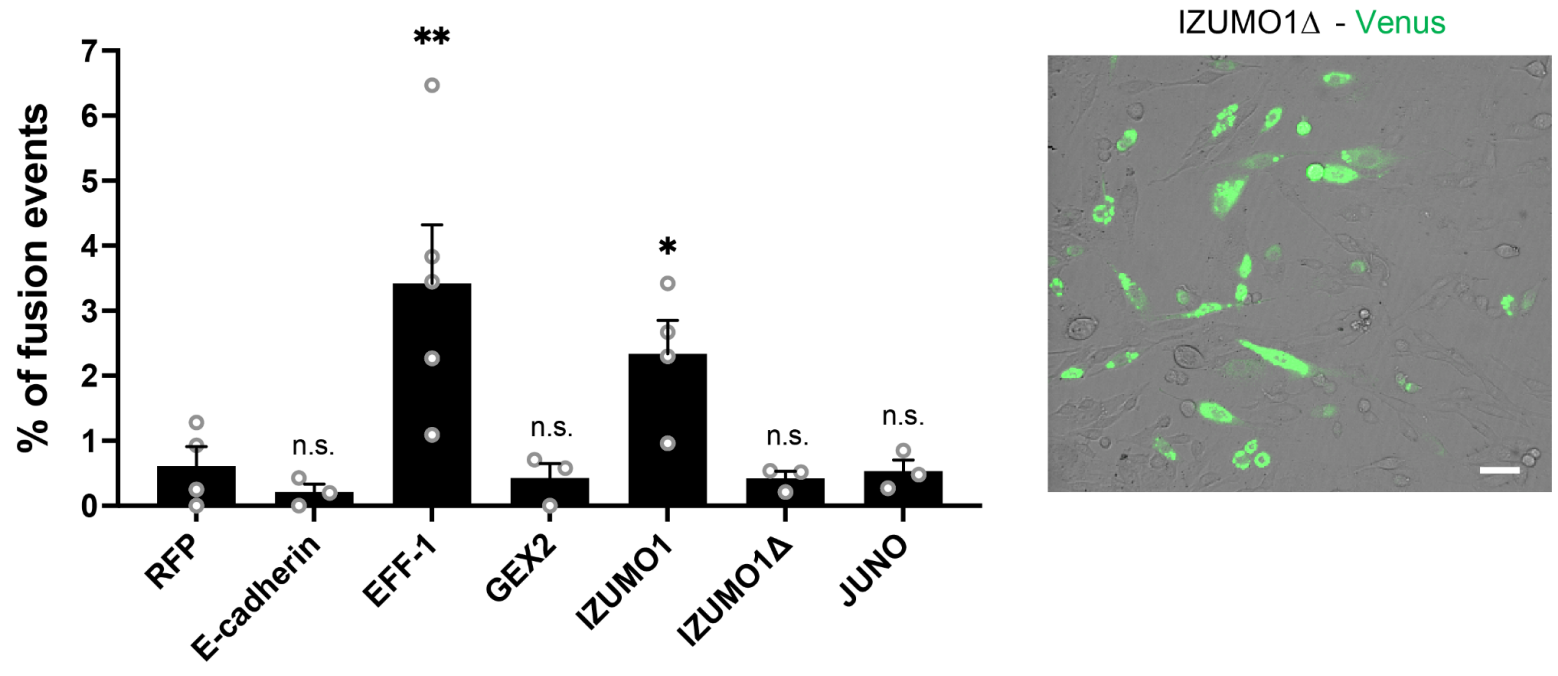

Figure 3 | Quantification of fusion activity using live imaging. (A) Time-lapse images from a fusion assay. BHK cells were transfected with plasmids for expression of cytoplasmic RFP (RFPcyto, magenta) and EFF-1 (co-transfection) or IZUMO1Venus (green). Arrowheads and arrows indicate contacting and fused cells, respectively. Time (h:min) after the start of observation (see Videos 1 and 2). Scale Bars, $50 \mu \mathrm{m}$. (B) Quantification of live imaging experiments in which BHK cells express RFPcyto, E-cadherin, EFF-1, GEX2, IZUMO1-Venus, IZUMO1A-Venus or JUNO. The percentage of fusion was defined as the ratio between the number of fusion events $(\mathrm{Fe})$ and the number of transfected cells $(\mathrm{Tc})$, as follows: \% of fusion $=(\mathrm{Fe} / \mathrm{Tc}) \times 100$. Bar chart showing individual experiments and means \pm SEM of at least three independent experiments. Comparisons by one-way ANOVA followed by Dunnett's test against RFPcyto. ns $=$ non-significant, ${ }^{*} p<0.05$, ${ }^{* *} p<0.01$. (C) Representative image showing the expression levels of IZUMO1 $\Delta$-Venus (green). Scale Bar, $50 \mu \mathrm{m}$. 


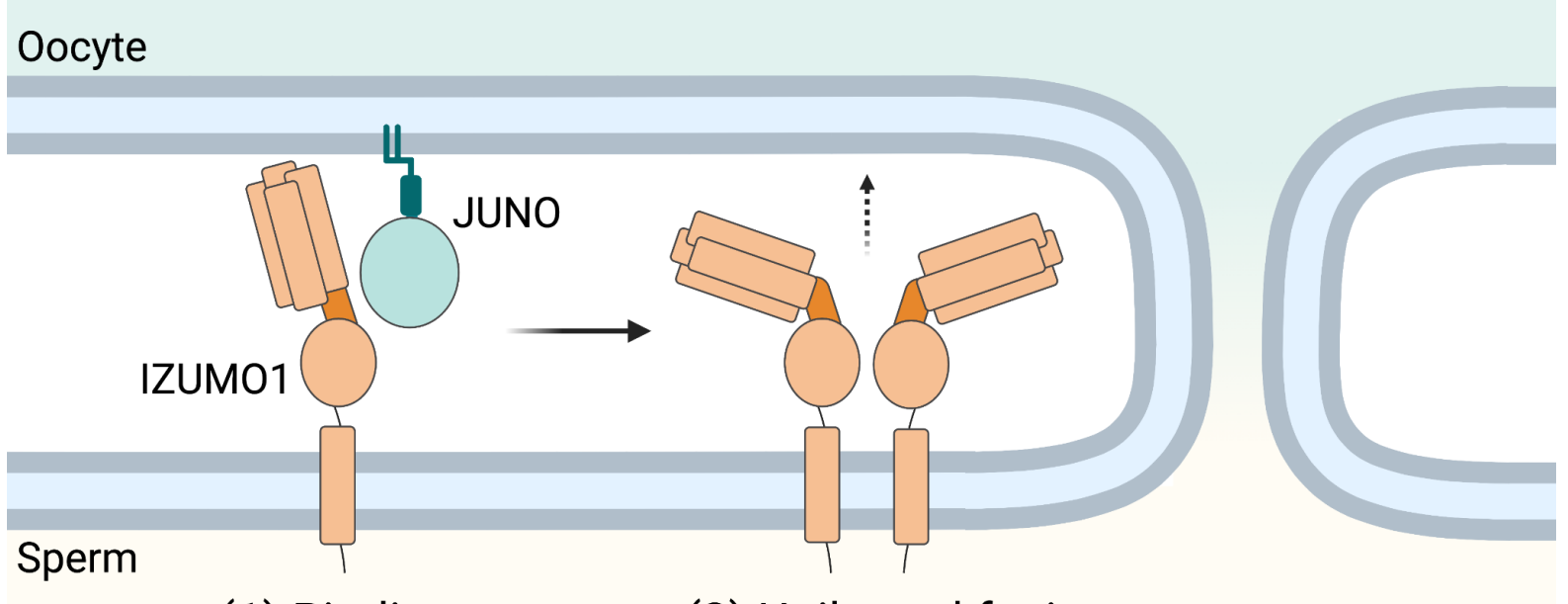

Figure 4 | Working model for IZUMO1 activities. 1. Transient interaction between JUNO and IZUMO1 ("Binding"). 2. Conformational change of IZUMO1, oligomerization (13) and unilateral induction of gamete fusion ("Unilateral fusion"). The hypothetical formation of IZUMO1 dimer driving membrane bending and pore formation. The $\beta-$ hairpin region is shaded with a darker orange. 
Supplementary Information for:

\section{IZUMO1 is a sperm fusogen}

Nicolas G. Brukman ${ }^{1 * \#}$, Kohdai P. Nakajima ${ }^{2 *}$, Clari Valansi ${ }^{1}$, Xiaohui Li ${ }^{1}$, Tetsuya Higashiyama ${ }^{2,3,4 \#}$, Benjamin Podbilewicz ${ }^{1 \#}$

${ }^{1}$ Department of Biology, Technion- Israel Institute of Technology, Haifa 32000, Israel

${ }^{2}$ Division of Biological Science, Graduate School of Science, Nagoya University,

Furo-cho, Chikusa-ku, Nagoya, Aichi 464-8602, Japan

${ }^{3}$ Institute of Transformative Bio-Molecules (WPI-ITbM), Nagoya University, Furo-cho, Chikusa-ku, Nagoya, Aichi 464-8601, Japan

${ }^{4}$ Department of Biological Sciences, Graduate School of Science, the University of

Tokyo, 7-3-1 Hongo, Bunkyo-ku, Tokyo 113-0033, Japan

*These authors contributed equally.

\#Correspondence and requests for materials should be addressed to N.G.B, T.H. or B.P.

This document contains: Material and Methods; Supplementary Figures 1-4; Supplementary Tables 1-3; Supplementary Movies Legends and Supplementary References.

\section{Materials and Methods}

Cell lines and DNA transfection

In this study we used BHK (CCL-10; ATCC, Virginia, USA) for multinucleation and content mixing experiments; BHK (RCB1423; RIKEN Cell Bank, Tsukuba, Japan), for live imaging assays and HEK293T (CRL-3216; ATCC) cells for content mixing experiments. BHK and HEK293T cells were grown and maintained in Dulbecco's modified Eagle's medium containing $10 \%$ foetal bovine serum (FBS). Cells were cultured at $37^{\circ} \mathrm{C}$ in $5 \% \mathrm{CO}_{2}$. Plasmids were transfected into cells using $2 \mu \mathrm{l}$ jetPRIME (PolyPlus-transfection, Illkirch-Graffenstaden, France) per $\mu \mathrm{g}$ of DNA in $100 \mu \mathrm{l}$ of reaction buffer for every $\mathrm{ml}$ of medium. For experiments with HEK293T cells, a coating with poly-L-lysine hydrobromide (Sigma, $20 \mu \mathrm{g} / \mathrm{ml}$ ) was applied to the plates.

\section{DNA constructs}

For the multinucleation and content mixing assays: Mouse Izumo1 and Juno coding sequences were amplified from pCMV6-IZUMO1-GFP (MG222708, Origene, 
Rockville, MD, USA) and pExpress1-JUNO (Clone B2) plasmids, respectively, kindly provided by Gavin Wright. The GFP tag of IZUMO1 construct was replaced with V5HIS tags during cloning. Izumo1-V5 and Juno sequences, and Arabidopsis thaliana GCS1HAP2-V5 were subcloned by restriction cloning into $\mathrm{pCl}:: \mathrm{H} 2 \mathrm{~B}-\mathrm{RFP}$ and $\mathrm{pCl}:$ :GFPnes vectors separately employing enzymes from Thermo Fisher Scientific (Invitrogen, Waltham, MA, USA). These bicistronic vectors translate for a nuclear RFP (H2B-RFP) or cytoplasmic GFP (GFPnes) after an IRES element (Internal Ribosome Entry Site). Oligonucleotides were from Sigma-Aldrich or IDT and all constructs were verified by DNA sequencing (Macrogen). For the live imaging experiments: Arabidopsis thaliana GEX2, Caenorhabditis elegans eff-1 and mouse Izumo or Juno sequences were amplified from cDNAs. To visualise the proteins, the fragments corresponding to GEX2 and Izumo1 were fused to fluorescent protein sequences by PCR and then cloned into pGENE $B$ after double digestion with restriction enzymes using the Gibson assembly (NEB, Ipswich, MA, USA). pGENE::mCherry-JUNO was made by ligating mCherry and pGENE::JUNO fragments (27). pGENE::IZUMO $\Delta$ Venus was prepared by self-ligation PCR performed based on pGENE::IZUMOVenus, and $\beta$-hairpin region (C135-L163) of IZUMO was deleted (27). For inducible expression using mifepristone in BHK cells, we used the GeneSwitch System (Invitrogen). The complete lists of plasmids and primers used in this study are shown in Supplementary Table 2 and Supplementary Table 3, respectively.

\section{$\underline{\text { Immunostaining and evaluation of multinucleation }}$}

BHK cells were grown on 24-well glass bottom tissue-culture plates. $24 \mathrm{~h}$ after plating, cells were transfected with pCl::myrGFP::H2B-RFP (myristoylated EGFP), pCl::GCS1/HAP-V5::H2B-RFP, pCl::IZUMO1-V5:H2B-RFP or pCl::JUNO::H2B-RFP vectors encoding for myristoylated EGFP (myrGFP, gray), GCS1/HAP2-V5, IZUMO1V5 or JUNO. For JUNO a plasmid for myrGFP (gray) was co-transfected. $24 \mathrm{~h}$ posttransfection, 20 M 5-fluoro-2'-deoxyuridine (FdUrd) was added to the plates to arrest the cell cycle and $24 \mathrm{~h}$ later, the cells were fixed with 4\% PFA in PBS and processed for immunofluorescence. To detect the tagged proteins immunofluorescence was performed with anti-V5 (R96025, Invitrogen) or anti-flag (F3165, Sigma) antibodies. The secondary antibody was Alexa Fluor 488 goat anti-mouse (A21202, Invitrogen), and nuclei were stained with $1 \mu \mathrm{g} / \mathrm{ml}$ DAPI. Micrographs were obtained using widefield illumination using an ELYRA system S.1 microscope (Plan-Apochromat 20X NA 0.8; Zeiss). Multinucleation percentage (Fig. S4) was determined as the ratio between the number of nuclei in multinucleated cells (NuM) and the total number of nuclei in multinucleated cells and expressing cells that were in contact but did not fuse (NuC) as follows: (Num/(Nuc + Num) $) \times 100$.

\section{Content mixing experiments}

BHK or HEK293T cells at $70 \%$ confluence in $35 \mathrm{~mm}$ plates were transfected with $1 \mu \mathrm{g}$ $\mathrm{pCl}:: \mathrm{H} 2 \mathrm{~B}-\mathrm{RFP}$ or $\mathrm{pCl}::$ GFPnes (empty plasmids as negative controls); pCl::GCS1/HAP2-V5::H2B-RFP or pCl::GCS1/HAP2-V5::GFPnes (positive control); 
pCl::IZUMO1-V5::H2B-RFP or pCl::IZUMO1-V5::GFPnes; $\mathrm{pCl}:: J U N O:: H 2 B-R F P$ or $\mathrm{pCl}:: J U N O:: G F P n e s .4 \mathrm{~h}$ after transfection, the cells were washed 4 times with DMEM with $10 \%$ serum, 4 times with PBS and detached using Trypsin (Biological Industries). The transfected cells were collected, resuspended in DMEM with $10 \%$ serum, and counted. Equal amounts of H2B-RFP and GFPnes cells (1-1.25 × $10^{5}$ each) were mixed and seeded on glass-bottom plates (12-well black, glass-bottom \#1.5H; Cellvis) and incubated at $37^{\circ} \mathrm{C}$ and $5 \% \mathrm{CO}_{2}$. For IZUMO1, pCl::IZUMO-V5::GFPnes cells were also mixed with pCl::H2B-RFP or pCl::JUNO::H2B-RFP transfected cells. $18 \mathrm{~h}$ after mixing, $20 \mu \mathrm{M}$ FdUrd was added to the BHK cells. The mixed cells were co-incubated for a total of $48 \mathrm{~h}$ after which they were fixed with 4\% PFA in PBS and stained with 1 $\mu \mathrm{g} / \mathrm{ml}$ DAPI. Micrographs were obtained using wide-field illumination using an ELYRA system S.1 microscope (Plan-Apochromat 20X NA 0.8; Zeiss). The percentage of mixing was defined as the ratio between the nuclei in mixed cells (NuM) and the total number of nuclei in mixed cells and fluorescent cells in contact that did not fuse (NuC), as follows: \% of mixing $=(\mathrm{NuM} /(\mathrm{NuM}+\mathrm{NuC})) \times 100$ (Fig. S4).

\section{$\underline{\text { Live imaging experiments }}$}

To evaluate fusion by live imaging, we transfected BHK cells with pGENE and pSWITCH. $24 \mathrm{~h}$ after transfection, BHK cells were cultured at $5.0 \times 10^{4}$ cells $/ \mathrm{ml} .4 \mathrm{~h}$ after transfection, the expression was induced by addition of $10^{-4} \mathrm{mM}$ mifepristone. 3$4 \mathrm{~h}$ post-induction, images of the cells were acquired every 6 min for $12 \mathrm{~h}$ to record cell-cell fusion, using a spinning disk confocal system (CellVoyager CV1000; Yokogawa Electric, Tokyo, Japan) at a magnification of 10X (NA 0.40, 10xUPLSAPO; Olympus, Tokyo, Japan) dry objective. The number of transfected cells and the occurrence of fusion were evaluated (Fig. S2). Image analyses were performed using CV1000 software (Yokogawa Electric) and the FIJI online tool was used to adjust the brightness and contrast. The percentage of fusion was defined as the ratio between the number of fusion events (Fe) and the number of transfected cells (Tc), as follows: $\%$ of fusion $=$ Fe/Tc (Fig. S4).

\section{Statistics and data analysis}

Results are presented as means \pm SEM. For each experiment we performed at least three independent biological repetitions. To evaluate the significance of differences between the averages we used one-way ANOVA as described in the legends (GraphPad Prism 9). Figures were prepared with Photoshop CS6 and Illustrator CS6 (Adobe), BioRender.com and FIJI (ImageJ 1.53c). 


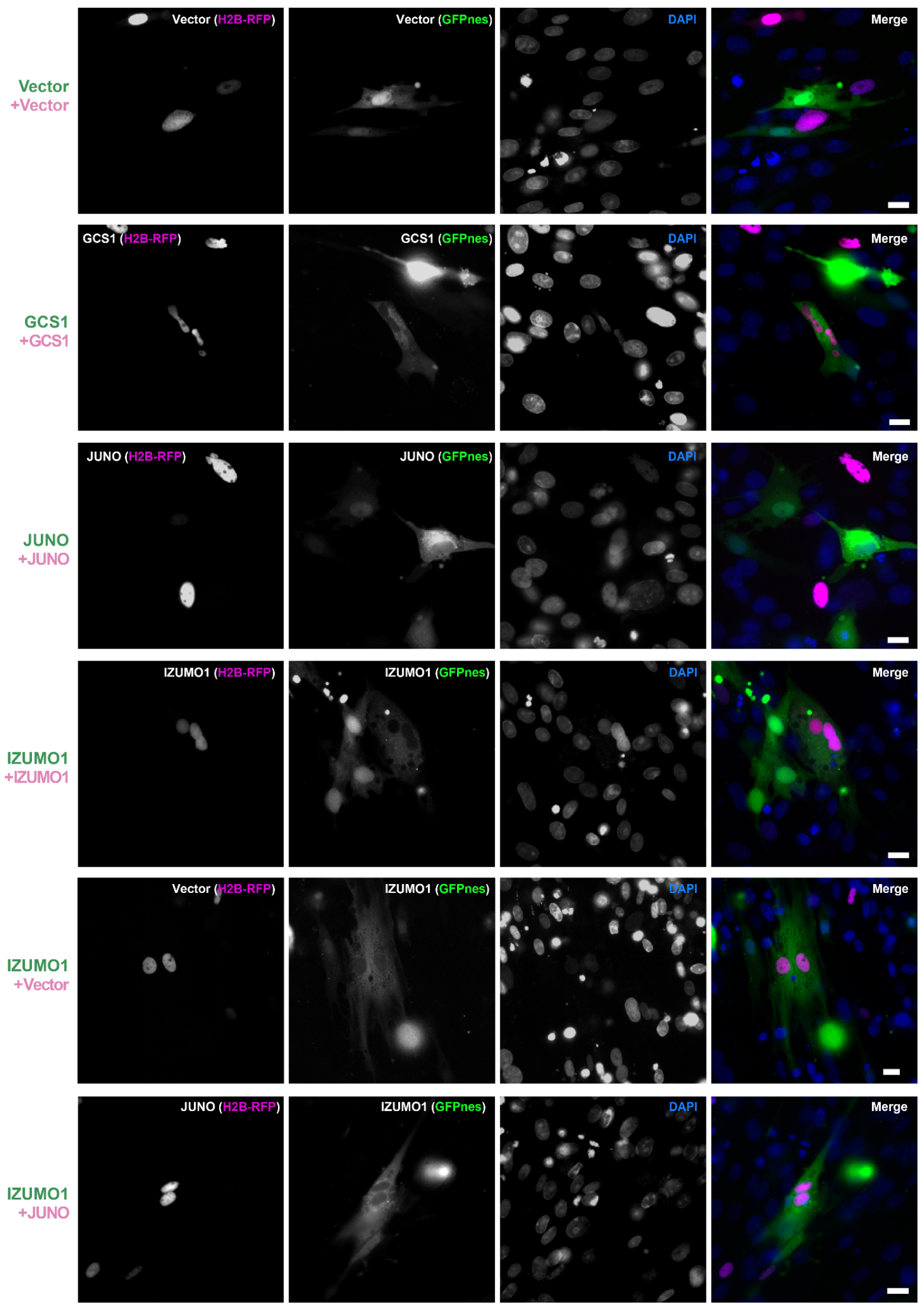

Supplementary Fig. 1 | Evaluation of fusion by content mixing of BHK cells. Images from Fig. 2A in each separate channel (red, green and DAPI) and merge. Scale bars, $20 \mu \mathrm{m}$. 


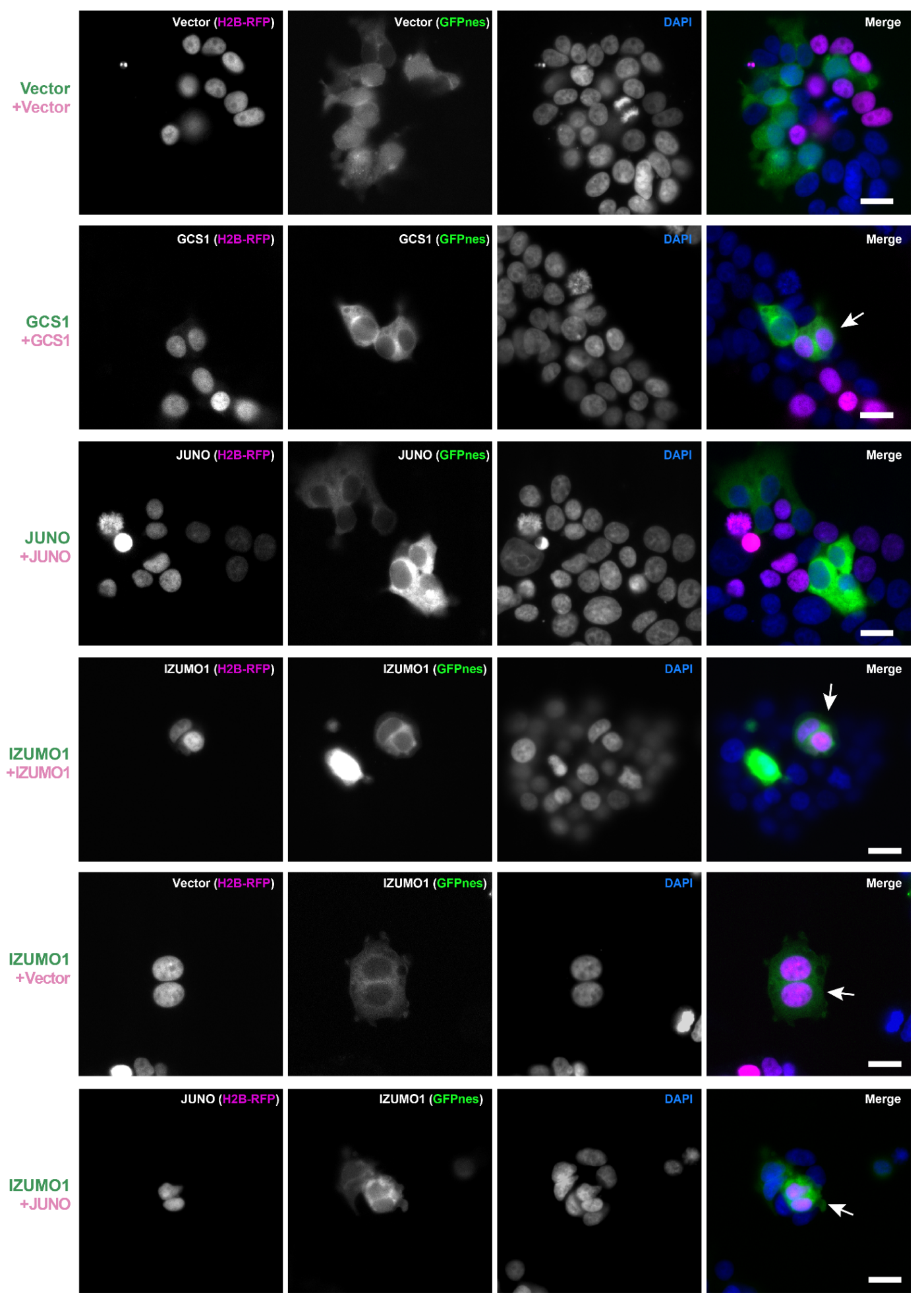

Supplementary Fig. 2 | Evaluation of cell fusion by content mixing of HEK293T cells. Images of mixed cells transfected with $\mathrm{pCl}:: G F P$ nes or $\mathrm{pCl}:: \mathrm{H} 2 \mathrm{~B}-\mathrm{RFP}$ empty or containing the coding sequence for the expression of GCS1/HAP2, IZUMO1 and JUNO as indicated in each panel. Arrows show fused cells containing both fluorescent markers, green cytoplasm (GFPnes) with red nuclei (H2B-RFP). DAPI staining is shown in blue. Each separate channel (red, green and DAPI) and merge are shown. Scale Bars, $20 \mu \mathrm{m}$. 


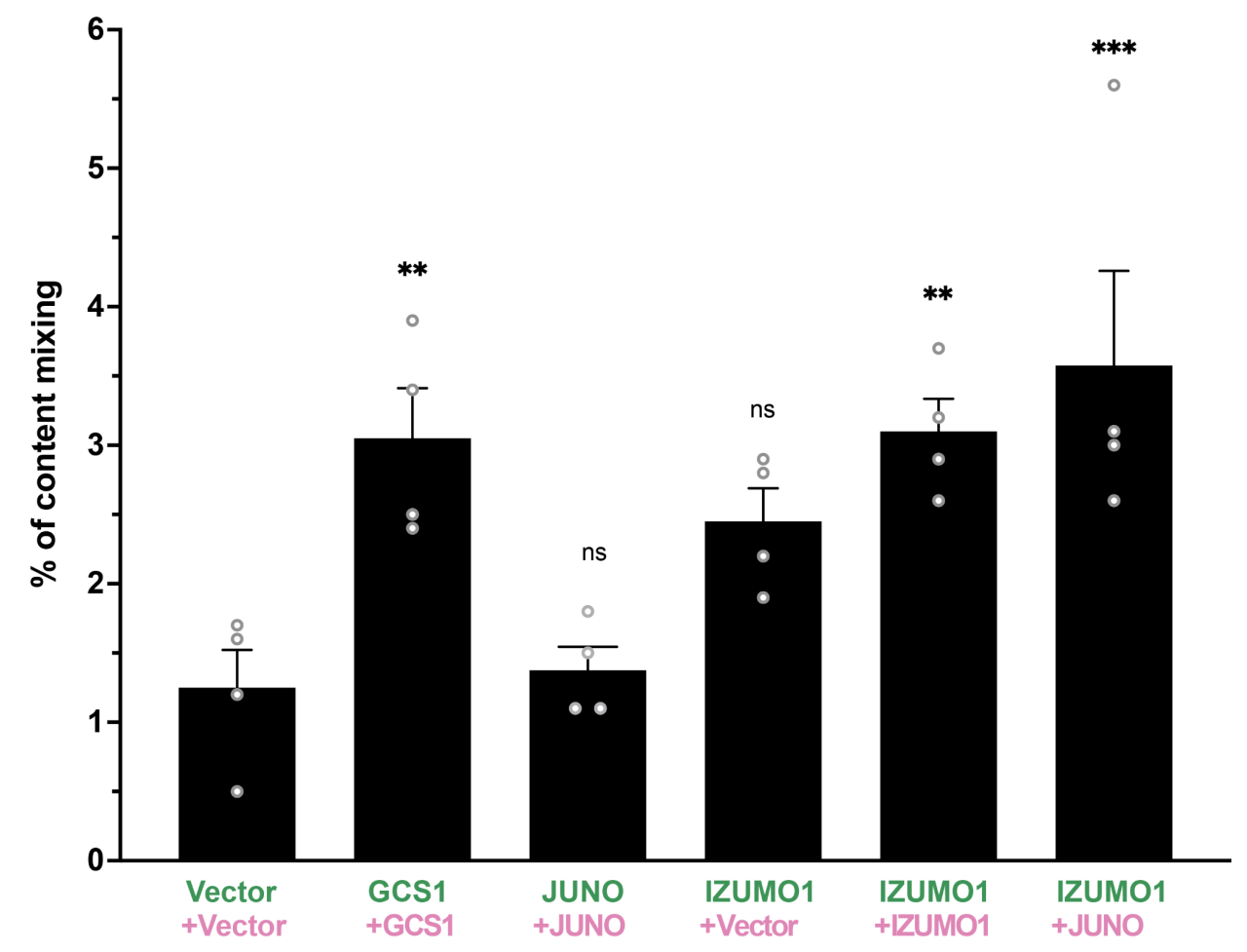

Supplementary Fig. 3 | Quantification of content-mixing experiments with HEK293T cells. The percentage of mixing was defined as the ratio between the nuclei in mixed cells (NuM) and the total number of nuclei in mixed cells and fluorescent cells in contact that did not fuse $(\mathrm{NuC})$, as follows: \% of mixing $=(\mathrm{NuM} /(\mathrm{NuM}+\mathrm{NuC})) \times 100$. Bar chart showing individual experiment values and means \pm SEM of four independent experiments. Comparisons by one-way ANOVA followed by Dunnett's test against the empty vectors. $n s=$ non-significant, ${ }^{* *} p<0.01,{ }^{* * *} p<0.001$. 


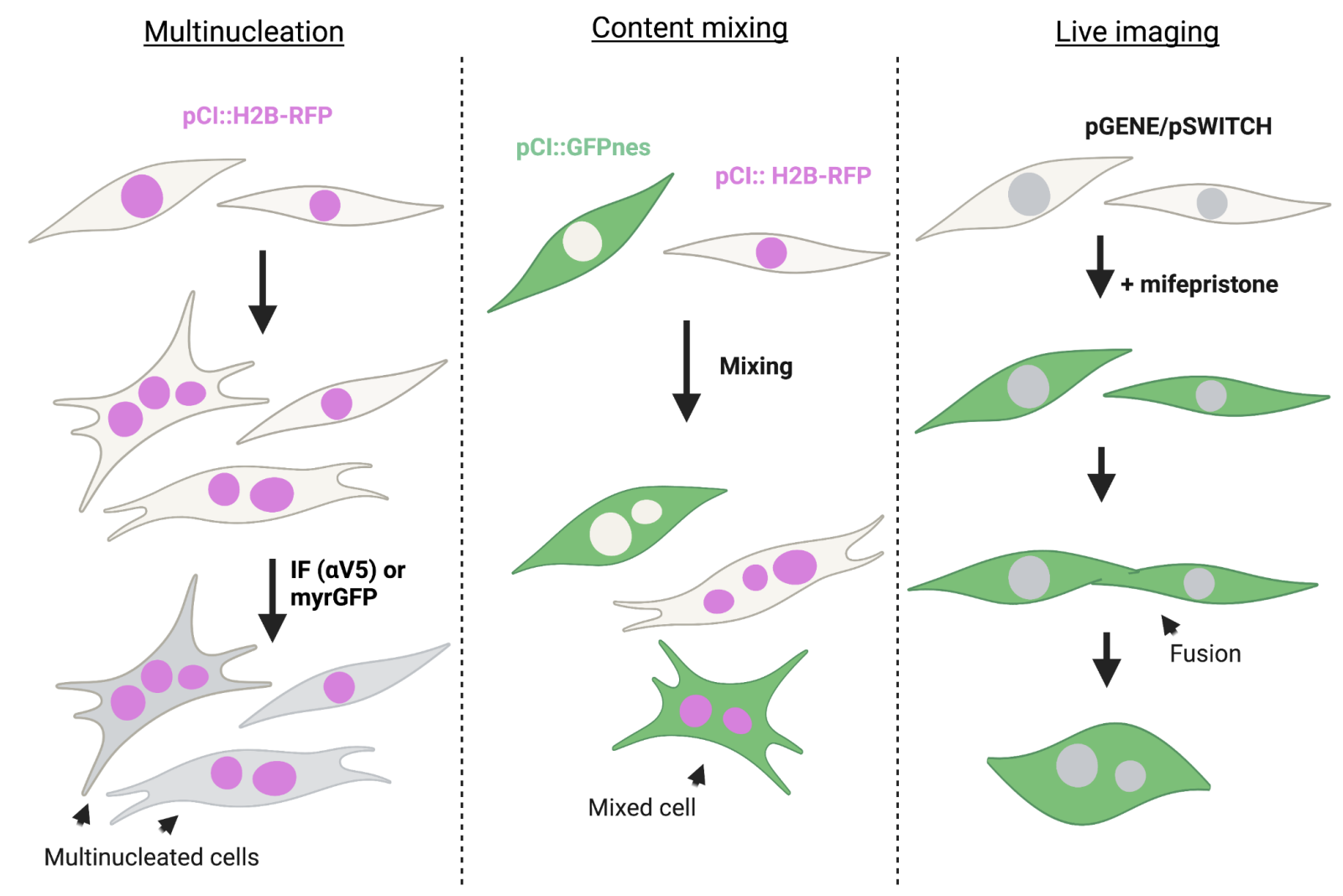

Supplementary Fig. 4 | Schemes of experimental designs. Multinucleation: BHK cells are transfected with pCl::myrGFP::H2B-RFP (myristoylated GFP), pCl::GCS1/HAP-V5::H2B-RFP, pCl::IZUMO1-V5:H2B-RFP or pCl::JUNO::H2B-RFP. For JUNO a plasmid for myrGFP (gray) was co-transfected and the formation of cells with more than one nucleus is quantified. The outline of the cells is observed by performing immunostaining (IF) with antibodies against the V5 tag (aV5) or by detection of myristoylated GFP (myrGFP) fluorescence. Content mixing: BHK or HEK293T cells were transfected with either a pCl::H2B-RFP or pCl::GFPnes plasmid for each candidate and mixed. The appearance of mixed cells containing both fluorescent markers was evaluated. Live imaging: BHK cells were transfected with plasmids from the pGENE/pSWITCH, the expression of the proteins induced by mifepristone and the cells were tracked by live imaging. The occurrence of fusion was registered and quantified. The signal corresponding to the fluorescent tags or fluorescent proteins co-expressed was also detected. 


\section{Movie legends}

Movie 1 | EFF-1-expressing cells showing bilateral fusion corresponding to Fig. $\mathbf{3 A}$.

Movie 2 | IZUMO1-expressing cells showing bilateral fusion corresponding to Fig. 3A.

\section{Supplementary Tables}

\begin{tabular}{|c|c|c|c|c|c|}
\hline \multicolumn{6}{|c|}{$\begin{array}{l}\text { Supplementary Table 1 I GCS1/HAP2 and IZUMO1 induce syncytia formation. } \\
\text { Data corresponding to Fig.1. Multinucleation was determined in four independent } \\
\text { experiments in BHKs expressing myristoylated GFP (myrGFP), GCS1/HAP2, } \\
\text { IZUMO1 or JUNO. Cells with } 2 \text { or more nuclei are considered multinucleated. }\end{array}$} \\
\hline & \multicolumn{5}{|c|}{ Number of cells with: } \\
\hline & 1 nucleus & 2 nuclei & 3 nuclei & 4 nuclei & 5 nuclei \\
\hline myrGFP & 3462 & 180 & 8 & 0 & 0 \\
\hline GCS1/HAP2 & 2202 & 439 & 39 & 1 & 0 \\
\hline IZUM01 & 2740 & 399 & 50 & 15 & 1 \\
\hline JUNO & 3400 & 232 & 3 & 0 & 0 \\
\hline
\end{tabular}




\section{Supplementary Table 2 | Plasmids used in this study}

\begin{tabular}{|c|c|c|c|}
\hline Plasmid name & Description & Use & Source \\
\hline pCl::H2B-RFP & $\begin{array}{l}\text { A CAG promoter (CMV immediate early enhancer and } \\
\text { chicken beta actin promoter) and IRES controlled } \\
\text { Histone2B-mRFP1 reporter. }\end{array}$ & $\begin{array}{l}\text { Multinucleation, Fig. } 1 \text { and } \\
\text { Content-mixing, Fig. } 2 .\end{array}$ & $\begin{array}{l}\text { Addgene plasmid \#92398 } \\
\text { (28) }\end{array}$ \\
\hline pNB32 / pCl::GFPnes & $\begin{array}{l}\text { A CAG promoter (CMV immediate early enhancer and } \\
\text { chicken beta actin promoter) and IRES controlled } \\
\text { EGFPnes (nuclear export signal) reporter. }\end{array}$ & Content-mixing, Fig. 2. & $(29)$ \\
\hline myr-EGFP & EGFP linked to a myristoylated and palmitoylated peptide & Multinucleation, Fig. 1. & $(30)$ \\
\hline MG222708 & pCMV6-AC-IZUMO1-GFP & Template for generating pNB4 & Origene, USA \\
\hline Mouse ZP2 (JD\#147) & pBluescript KS - mZP2 & Used for generating pOAB207. & $\begin{array}{l}\text { Addgene plasmid \#14645 } \\
\text { (31) }\end{array}$ \\
\hline pOAB207 & plZT::mZP2-V5-6HIS & $\begin{array}{l}\text { Intermediate construct for } \\
\text { generating pOAB210. }\end{array}$ & \begin{tabular}{|l|} 
This study, cloned using \\
EcoRl and Notl enzymes
\end{tabular} \\
\hline pOAB210 & pCAGGS::mZP2-V5-6HIS & $\begin{array}{l}\text { Intermediate construct for } \\
\text { generating pNB4. }\end{array}$ & $\begin{array}{l}\text { This study, cloned using } \\
\text { EcoRl and Notl enzymes }\end{array}$ \\
\hline pNB4 & pCAGGS::IZUMO1-V5-6HIS & $\begin{array}{l}\text { Intermediate construct for } \\
\text { generating pNB36 and pNB37. }\end{array}$ & $\begin{array}{l}\text { This study, cloned using } \\
\text { EcoRl and Xhol } \\
\text { enzymes. }\end{array}$ \\
\hline pExpress1-JUNO & pExpress1-JUNO (mouse sequence, Clone B2) & $\begin{array}{l}\text { Template for generating pNB11 } \\
\text { and pNB35. }\end{array}$ & (4) \\
\hline pXL29 & pCl::AtGCS1/HAP2-V5::H2B-RFP & $\begin{array}{l}\text { Multinucleation, Fig. } 1 \text { and } \\
\text { Content-mixing, Fig. } 2 \text {. }\end{array}$ & (29) \\
\hline pXL45 & pCl::AtGCS1/HAP2-V5::GFPnes & Content-mixing, Fig. 2. & $\begin{array}{l}\text { This study, cloned using } \\
\text { Nhel and Smal enzymes. }\end{array}$ \\
\hline pNB11 & pCl::JUNO::H2B-RFP & $\begin{array}{l}\text { Multinucleation, Fig. } 1 \text { and } \\
\text { Content-mixing, Fig. } 2 .\end{array}$ & $\begin{array}{l}\text { This study, cloned using } \\
\text { Nhel and Smal enzymes. }\end{array}$ \\
\hline pNB35 & pCl::JUNO::GFPnes & Content-mixing, Fig. 2. & $\begin{array}{l}\text { This study, cloned using } \\
\text { Nhel and Smal enzymes. }\end{array}$ \\
\hline pNB36 & pCl::IZUMO1-V5-6HIS::H2B-RFP & $\begin{array}{l}\text { Multinucleation, Fig. } 1 \text { and } \\
\text { Content-mixing, Fig. } 2 .\end{array}$ & $\begin{array}{l}\text { This study, cloned using } \\
\text { Nhel and Smal enzymes. }\end{array}$ \\
\hline pNB37 & pCl::IZUMO1-V5-6HIS::GFPnes & Content-mixing, Fig. 2. & $\begin{array}{l}\text { This study, cloned using } \\
\text { Nhel and Smal enzymes. }\end{array}$ \\
\hline pGene/V5-His & pGene/V5-His & $\begin{array}{l}\text { GeneSwitch }{ }^{\mathrm{TM}} \text { inducible } \\
\text { Mammalian Expression / Live } \\
\text { imaging, Fig. } 3 .\end{array}$ & INVITROGEN \\
\hline pSwitch & pSwitch & $\begin{array}{l}\text { Regulatory vector for } \\
\text { Mifepristone induction / Live } \\
\text { imaging, Fig. } 3 \text {. }\end{array}$ & INVITROGEN \\
\hline pRFPnes & DsRed2 with a nuclear export signal & Live imaging, Fig. 3. & (6) \\
\hline Mouse E-cadherin GFP & Mouse E-cadherin coding sequence in pEGFP-N1 vector & Live imaging, Fig. 3 & $\begin{array}{l}\text { Addgene plasmid \#67937 } \\
\text { (32) }\end{array}$ \\
\hline pKPN167 & pGENE::mCherry-JUNO & Live imaging, Fig. 3. & $(27)$ \\
\hline pKPN70 & pGENE::IZUMO1-Venus & Live imaging, Fig. 3. & (27) \\
\hline pKPN95 & pGENE::IZUMO1 & Live imaging, Fig. 3. & (27) \\
\hline pOA34 & pGENE::CeEFF-1 & Live imaging, Fig. 3. & (7) \\
\hline pKPN67 & pGENE::AtGEX2-Venus & Live imaging, Fig. 3. & $\begin{array}{l}\text { This study, cloned using } \\
\text { Kpnl and Notl enzymes. }\end{array}$ \\
\hline
\end{tabular}


bioRxiv preprint doi: https:/doi.org/10.1101/2022.02 01.478669; this version posted February 3, 2022. The copyright holder for this preprint (which was not certified by peer review) is the author/funder, who has granted bioRxiv a license to display the preprint in perpetuity. It is made available under aCC-BY-NC-ND 4.0 International license.

\begin{tabular}{|c|c|c|}
\hline \multicolumn{3}{|c|}{ Supplementary Table 3 | Primers used for this study } \\
\hline Primer name & Sequence $5^{\prime}->3^{\prime}$ & Description \\
\hline ZP2 F EcoRI & GCGAATTCATGGCGAGGTGGCAGAGGAAAG & $\begin{array}{l}\text { Forward primer for cloning } m Z P 2 \text { into plZT and pCAGGS with } \\
\text { EcoRI }\end{array}$ \\
\hline ZP2 R Notl & TGGGCGGCCGCCGTGATTGAACCTTATAGTTCTTTTC & Reverse primer for cloning $m Z P 2$ into plZT with Notl \\
\hline ZP2 R Nhel & CTTACGCTAGCTCAATGGTGATGGTGATGATG & Reverse primer for cloning $m Z P 2$ into $p C A G G S$ with Nhel \\
\hline Izumo1 F EcoRI & CCGGGAATTCGGTCGACTGGATCC & Forward primer for cloning Izumo 1 into pCAGGS with EcoRI \\
\hline Izumo1 R Xhol & TCCATCTCGAGGGCCGCGTACG & Reverse primer for cloning Izumo1 into pCAGGS with Xhol \\
\hline Izumo1 F Nhel & TTATCGCTAGCGAATTCGGTCGACTGGATCC & $\begin{array}{l}\text { Forward primer for cloning Izumo1 into pCl::H2B-RFP and } \\
\text { pCl::GFPnes vectors with Nhel }\end{array}$ \\
\hline Izumo1 R Smal & GTCCCCCGGGGCTCAATGGTGATGGTGATGATG & $\begin{array}{l}\text { Reverse primer for cloning Izumo1 into pCl::H2B-RFP and } \\
\text { pCl::GFPnes vectors with Smal }\end{array}$ \\
\hline Juno F Nhel & TAAGCTAGCCTCTTTGGCATCAGGAGGAGC & $\begin{array}{l}\text { Forward primer for cloning Juno into pCl::H2B-RFP and } \\
\text { pCl::GFPnes vectors with Nhel }\end{array}$ \\
\hline Juno R Smal & ATACCCCGGGTGCCCCCAACATGAATAGCC & $\begin{array}{l}\text { Reverse primer for cloning Juno into pCl::H2B-RFP and } \\
\text { pCl::GFPnes vectors with Smal }\end{array}$ \\
\hline GCS1 F Nhel & CTAGCTAGCGGTACCATGGTGAACGCGATTTTAATG & $\begin{array}{l}\text { Forward primer for cloning GCS1/HAP2 into pCl::H2B-RFP } \\
\text { and pCl::GFPnes vectors with Nhel }\end{array}$ \\
\hline GCS1 R Smal & TCCCCCGGGCTAATGGTGATGGTGATGATGACC & $\begin{array}{l}\text { Reverse primer for cloning GCS1/HAP2 into pCl::H2B-RFP } \\
\text { and pCl::GFPnes vectors with Smal }\end{array}$ \\
\hline GEX2 F Kpnl & $\begin{array}{l}\text { TCACAGGCCACCAAGCTTGGTACCATGGCGATTAAATT } \\
\text { CGTTTCAC }\end{array}$ & $\begin{array}{l}\text { Forward primer for generating and cloning Gex2-venus into } \\
\text { pGENE vector with Kpnl }\end{array}$ \\
\hline GEX2 R & $\begin{array}{l}\text { GCTGCCCCCTCCACCTGACTGCTTATTCTGGTTGCCGG } \\
\text { AAG }\end{array}$ & Reverse primer for generating Gex2-venus \\
\hline Venus $\mathrm{F}$ & $\begin{array}{l}\text { TCAGGTGGAGGGGGCAGCGGGGGGGGAGGTATGGTG } \\
\text { AGCAAGGGCGAG }\end{array}$ & Forward primer for generating Gex2-venus \\
\hline Venus R Notl & $\begin{array}{l}\text { GTGACCTCGAGCGGCCGCTTACTTGTACAGCTCGTCC } \\
\text { ATGCC }\end{array}$ & $\begin{array}{l}\text { Forward primer for generating and cloning Gex2-venus into } \\
\text { pGENE vector with Notl }\end{array}$ \\
\hline
\end{tabular}

